\title{
RELATIVE PLANTING TIMES ON THE PRODUCTION COMPONENTS IN SESAME/COWPEA BEAN INTERCROPPING IN ORGANIC SYSTEM
}

\author{
Épocas relativas de plantio sobre os componentes da produção no consórcio \\ gergelim/feijão caupi em sistema orgânico de cultivo
}

\author{
Afrânio César de Araújo, Magdi Ahmed Ibrahim Aloufa², Apolino José Nogueira da Silva ${ }^{3}$, \\ Walter Esfrain Pereira ${ }^{4}$, Cosme Jales de Oliveira ${ }^{3}$
}

\begin{abstract}
Aiming at better land use, small farmers usually plant sesame and cowpea bean intercropped with other crops. The aim of this work was to analyze and quantify the influence of four relative planting times of the cowpea bean in intercropping with sesame from the standpoint of their production components, plant productivity and the index of land equivalent ratio (LER). The field experiment was conducted in a randomized blocks with four treatments and four replicates. The treatments were the sesame and the cowpea bean in intercropping with the cowpea bean planted at the same time, 7, 14 and 21days after than the sesame. A greater part of the production components of both the sesame as well the cowpea bean was affected by the intercropping and significant differences were noted among the treatments in a larger part of the parameters. As the planting of the cowpea bean became more distant from that of the sesame, the yield of the Pedaliaceae increased and the yield of the Fabaceae decreased. The results for LER findings on the other hand suggest that in the sesame/cowpea bean intercropping, when the Fabaceae is planted seven days after the sesame, there is better use of the land and a largest possibility to the producer earning a profit.
\end{abstract}

Index terms: Intercrop, food crops, family farm.

\section{RESUMO}

Objetivando otimizar o uso da terra, pequenos produtores comumente cultivam gergelim e feijão caupi em consórcio com outras culturas. Objetivou-se, com este trabalho,analisar e quantificar a influência de quatro épocas relativas de plantio do feijão caupi no consórcio com o gergelima partir dos componentes de produção, produtividade vegetal e índice de uso eficiente da terra (UET). Um experimento de campo foi conduzido em delineamento de blocos casualizados com 4 tratamentos e 4 repetições. Os tratamentos constaram dos plantios consorciados entre as duas culturas, sendo a Fabaceae plantada no mesmo dia que o gergelim, 7, 14 e 21 dias após a Pedaliaceae. A maior parte dos componentes da produção, tanto do gergelim como do feijão caupi, foi afetada pelo consórcio, tendo sido verificadas diferenças significativas entre os tratamentos para a maior parte das variáveis. Conforme distanciou-se a semeadura do feijão caupi, aumentou-se o rendimento da Pedaliaceae e diminuiu-se o rendimento da Fabaceae. Os resultados encontrados para o UET sugerem que, no consórcio gergelim/feijão caupi, quando a Fabaceae é plantada 7 e 14 dias após o gergelim, há melhor aproveitamento da área e maior possibilidade de ganhos líquidos para o produtor.

Termos para indexação: Consórcio, culturas alimentares, agricultura familiar.

(Received in august 8, 2013 and approved in november 4, 2013)

\section{INTRODUCTION}

Sesame (Sesamum indicum L.), of the Pedaliaceae family is a well known oil seed plant, one of the oldest to have been cultivated for over 5000 years (ALBUQUERQUE et al., 2012). At present planted in several countries, the largest producers are India (893000 t), Mianmar (880 $000 \mathrm{t}$ ), China (587 $947 \mathrm{t}$ ) and Ethiopia (260 $534 \mathrm{t}$ ) (FAO, 2013). The Brazil still produces a small amount. The highest Brazilian producers are in the states of Goiás, São Paulo, Mato Grosso and Minas Gerais. In northeast Brazil its cultivation is restrict to small properties using traditional planting methods (ARRIEL; BELTRÃO; FIRMINIO, 2009). Sesame is a plant well adapted to hot climates whose optimum temperature for growth is between 24 and $27{ }^{\circ} \mathrm{C}$ (ALBUQUERQUE et al., 2012). It presents roots that have a great capacity of penetrating the soil. Thus, it is a drought resistant crop (LANGHAM, 2007). Nonetheless, for it to produce satisfactorily it requires approximately 400 to 500 $\mathrm{mm}$ of water along its growth productive cycle. Sesame seeds are rich in calcium and potassium and its high quality and stable oil have a high index of sesamin and sesamolin

\footnotetext{
${ }^{1}$ Universidade Federal do Rio Grande do Norte/UFRN - Unidade Acadêmica Especializada em Ciências Agrárias - RN 160 - km 03 - S/N - Distrito de Jundiaí - 59280-000 - Cx. P. 07 - Macaíba - RN - Brasil - afranio@eaj.ufrn.br

${ }^{2}$ nniversidade Federal do Rio Grande do Norte/UFRN - Departamento de Botânica Ecologia e Zoologia - Natal - RN - Brasil

3Universidade Federal do Rio Grande do Norte - Unidade Acadêmica Especializada em Ciências Agrárias - Macaíba - RN - Brasil

${ }^{4}$ Universidade Federal da Paraíba/UFPB - Areia - PB - Brasil
} 
antioxidants as well as monounsaturated and polyunsaturated fatty acids (RANGKADILOK et al., 2010), which is substantially used by pharmaceutical and cosmetic industries (SUDDHIYAM, et al., 2009).

In brazilian northeast, specially due to its ample adaptability to the most variable edaphic and climatic conditions, the cowpea bean [Vigna unguiculata (L.) Walp.], also known as macassar bean, string bean or vigna bean, is basically cultivated for subsistence (ANDRADE JÚNIOR et al., 2003). In the State of Rio Grande do Norte, Brazil, 92\% of cultivated bean is the cowpea bean and the other $8 \%$ is divided among the common bean and fava bean. The cowpea bean is of great significance in the socioeconomic state structure, been a valuable source of proteins, carbohydrates, vitamins, minerals and fibers (LIMA et al., 2010). Cowpea bean has a short cycle and a high tolerance to water shortage. Furthermore, it's a rustic culture which allows it to grow in infertile soil (ANDRADE JÚNIOR et al., 2003).

Aiming at better land use, small farmers usually plant sesame and cowpea bean intercropped with other crops. In an intercrop agroecosystem, the need for nitrogen fertilizer is reduced (BEDOUSSAC; JUSTES, 2011), the risk of cultivation failure is smaller for there are larger options of food supply, more efficient land use, reduction of seasonality of manpower as is planting cost. Besides, intercropping exerts better control of weed growth, better use of residues, increase in the level of organic matter and biologic activity of the soil, increase conservation and less exposure of the soil to sun radiation (ARRIEL; BELTRÃO; FIRMINO, 2009). Intercropping are perceived as a more efficient production system not only by having better yield per unit area but also by the increased efficiency in the use resources and by providing a better income for farmers (BHATTI et al., 2013). At level of family farm, the negative point of intercropping of cultures would be the higher competition for water, light and nutrients that tend to diminish to a higher or lower the degree of profitability of each separate crop. However, according to Van Asten (2011), intercropping benefits may increase through the correct use and management of the soil, plant density and planting configuration.

Problems related to species choices and planting times can very well hinder a polycultural agroecological system. As to the choice of the better planting time of one crop in relation to another in intercrop is among the problems related to the multiple crops in Brazil and in other developing countries. It isa particular critical factor towards a stable competitive relationship in intercropping directly affecting the yield of each culture, the best use of the area plus soil conservation (BELTRÃO et al., 2010; EGBE, 2010). Thus, the aim of this work was to analyze and quantify the influence of four relative planting times of the cowpea bean in sesame/cowpea bean intercropping carefully checking the production components, the vegetable productivity and the index of land equivalent ratio.

\section{MATERIAL AND METHODS}

This study was conducted at the Jundiaí Agricultural School/UECIA/UFRN located in the township of Macaíba in the State of Rio Grande do Norte, Brazil, at $5^{\mathrm{p}} 53^{\prime}$ S and $35^{\mathrm{p}} 23^{\prime}$ ' $\mathrm{W}$ median altitude of $40 \mathrm{~m}$ above the sea level. The local climate equates a transition between types As' and BSh' of the Köppen system, having an average temperature of $26^{\circ} \mathrm{C}$ and rains in autumn and winter (BELTRÃO et al., 2005).

To increase the contents of organic matter in the experimental area $30 \mathrm{~m}^{3} \mathrm{ha}^{-1}$ of poultry litter were applied and to correct the soil composition dolomitic limestone were added based on the chemical analysis of the soil at the rate of $1700 \mathrm{~kg} \mathrm{ha}^{-1}$. The chemical and physical characteristics of the soil were the following: $\mathrm{pH}$ in water $=$ $6.13, \mathrm{Ca}=0.88 \mathrm{cmolcdm}^{-3}, \mathrm{Mg}=0.33 \mathrm{cmolcdm}^{-3}, \mathrm{Al}=0.00$ $\mathrm{cmolcdm}^{-3}, \mathrm{H}=1.82 \mathrm{cmolcdm}^{-3}, \mathrm{P}=22.00 \mathrm{mgdm}^{-3}, \mathrm{~K}=73.00$ $\mathrm{mgdm}^{-3}, \mathrm{Na}^{+1}=6.00 \mathrm{mg} \mathrm{dm}^{-3}, \mathrm{Fe}=12.00 \mathrm{mgdm}^{-3}, \mathrm{Zn}=2.14$ $\mathrm{mgdm}^{-3}, \mathrm{Cu}=0.21 \mathrm{mgdm}^{-3}$ and $\mathrm{Mn}=2.74 \mathrm{mg} \mathrm{dm}^{-3}$.

The experiment was conducted in randomized blocks with 4 treatments and 4 replicates. The treatments were the sesame/cowpea bean intercropping with the two crops planted at the same time, sesame/cowpea bean intercropping with the cowpea bean planted 7 days after than the sesame, sesame/cowpea bean intercropping with the cowpea bean planted 14 days after than the sesame and sesame/cowpea bean intercropping with the cowpea bean planted 21 days after than the sesame.

BRS Seda (sesame) and BRS Potiguar (cowpea bean) were the cultivars used for the planting. The spacing adopted for the sesame was of double rows $1.7 \times 0.3 \times 0.1$ $\mathrm{m}$, having a row of the Fabaceae between the wider spacing of Pedaliaceae in intercropping with a spacing of $0.25 \mathrm{~m}$ between plants in rows. In the monocropping of the cowpea bean the spacing was $0.6 \times 0.5 \mathrm{~m}$. To supply the needed water to the crops were carried out irrigations by microaspersion with timed rotations of watering and length of irrigation according to the different stages of the sesame. A laminar flow of water of $800 \mathrm{~mm}$ was distributed during the 90 days period of the Pedaliaceae cycle. As for as the sesame several parameters were analyzed: yield, height of first fruit, mass of 1000 seeds, number of fruit per plant and number of fruitful branches. For the cowpea bean were 
analyzed of 100 seeds, number of seeds per pod and number of pods per plant.

To evaluate the viability of intercropping taking into consideration the related area of soil under a single crop the index of land equivalent ratio (LER) was applied. Plots with the single crops were planted in each block to obtain LER. Data were statistically analyzed using analysis of variance ( $F$ test) and regression analysis, using Assistat software, Version 7.5 beta.

\section{RESULTS AND DISCUSSION}

The analysis of the obtained values for the sesame yield in intercropping in relationto each relative planting times of the Fabaceae, allowed to notice a linearincrease in the productivity of the Pedaliaceae when the planting of the Fabaceae was retarded (Figure 1A).Nevertheless, the correct choice of the better planting of the cowpea bean would be depend on the other parameters. The planting of cowpea bean among the rows of the sesame began an interspecific competition for ecological substrate (water, light and nutrients) that brought about a decline in the yield of the oilseed. As the level of the water supply were maintained at adequate levels for both crops during the experiment it is probable that the competition for nutrients and light was the key factor in the reduction of the yield of the sesame in the intercrop.

The maximum yield found by Udom Fagam and Ekwere (2006) for the intercropping of sesame and cowpea bean in a rainfeed watering system in northeastern Nigeria was $495 \mathrm{ka} \mathrm{ha}^{-1}$. In the northeast of Nigeria, Ogbonna and Umar-Shaaba (2011) reached a yield of $1495 \mathrm{~kg} \mathrm{ha}^{-1}$ using a local cultivar of sesame in monocropping in a soil fertilized with manure and water with a rain system indexed at 970 mm during the ongoing culture cycle. Doğan and Zeybek (2009) in Turkey reached a yield of $1349 \mathrm{~kg} \mathrm{ha}^{-1}$ with the irrigated Galmara variety in a conventional system of farming. Bhatti, Ahamad and Nazir (2005), studying irrigated sesame intercropped with several Fabaceae in Faisalabad, Pakistan, observed a more aggressive competitive behavior on the part of cowpea when compared to the others species, which was reflected in a reduction of $26.00 \%$ in the yield with sesame in intercropping.
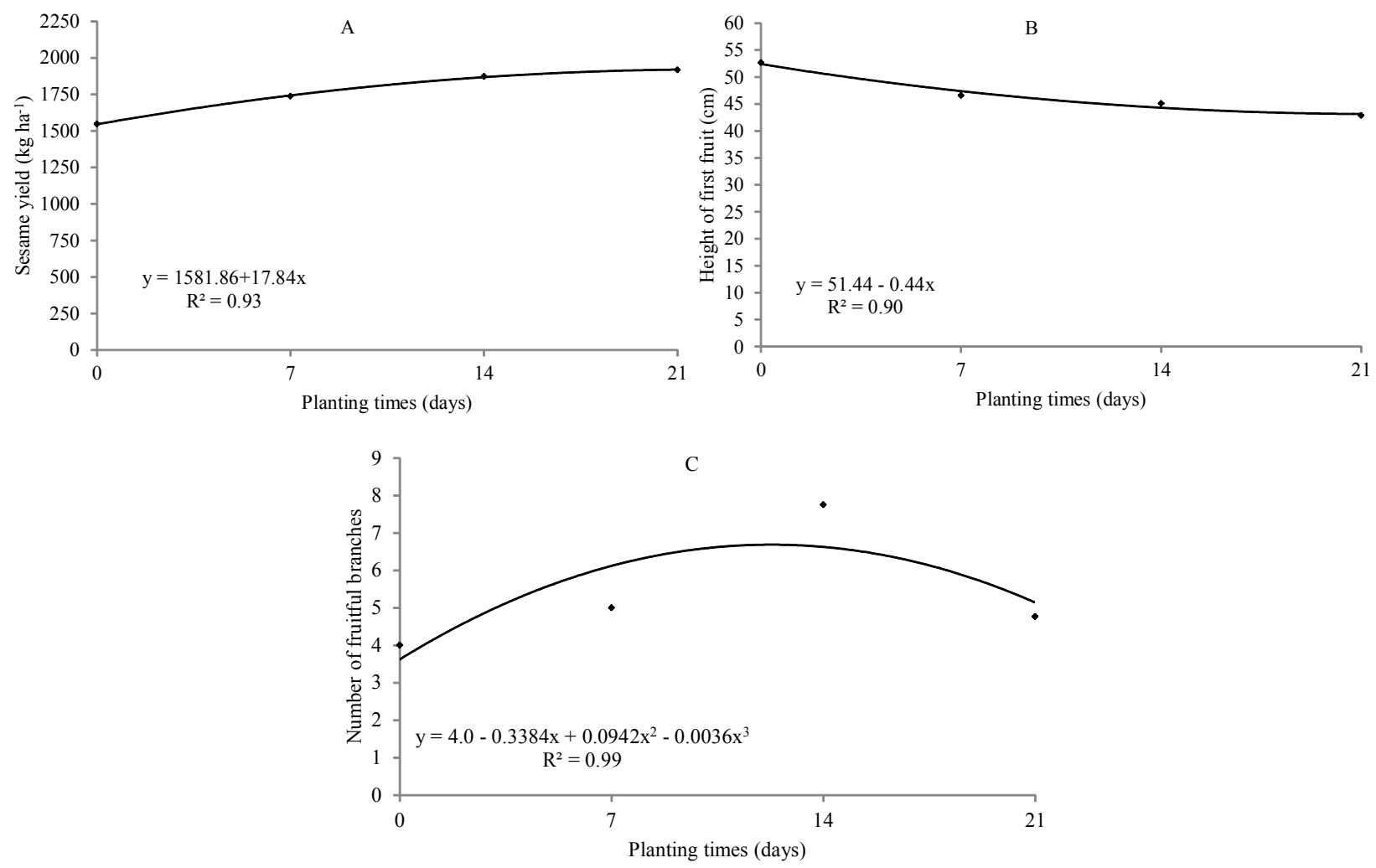

Figure 1 - Influence of the relative planting times of the cowpea bean on sesame yield (A), height of first fruit (B) and number of fruitful branches (C). Macaíba, Rio Grande do Norte, 2012.

Ciênc. agrotec., Lavras, v. 37, n. 6, p. 531-537, nov./dez., 2013 
A direct influence of the planting times was noted as to the height of the insertion of the first fruit. It was noticed a progressive approximation of the first fruit at the base of the plant as the timing for co-planting cowpea bean was retarded. The average found for the treatment 21 days was of $40.60 \mathrm{~cm}$ while the treatment 0 day showed the highest value (52.67) (Figure 2B).

There was no significant effect of the treatments as far as the variable mass of 1000 seeds. The medium values found in this work were superior to those obtained by Ozkan, Curat and Kulak (2012) for 10 genotypes studied in Killis, Turkey using a rainfeed watering system but inferior as to those found by Dogan and Zeybek (2009) for varieties Muganli - 51, Ozbek - 82 and Galmarmara. Using less spacing between plants and comparing with the single culture, Batthi, Ahmad and Nazir (2005) noted reduction of $7.18 \%$ in the medium value for this variable when sesame was intercropped with cowpea bean. According to Arriel, Beltrão and Firmino (2009), 1000 seeds of sesame weigh on the average $3.00 \mathrm{~g}$.
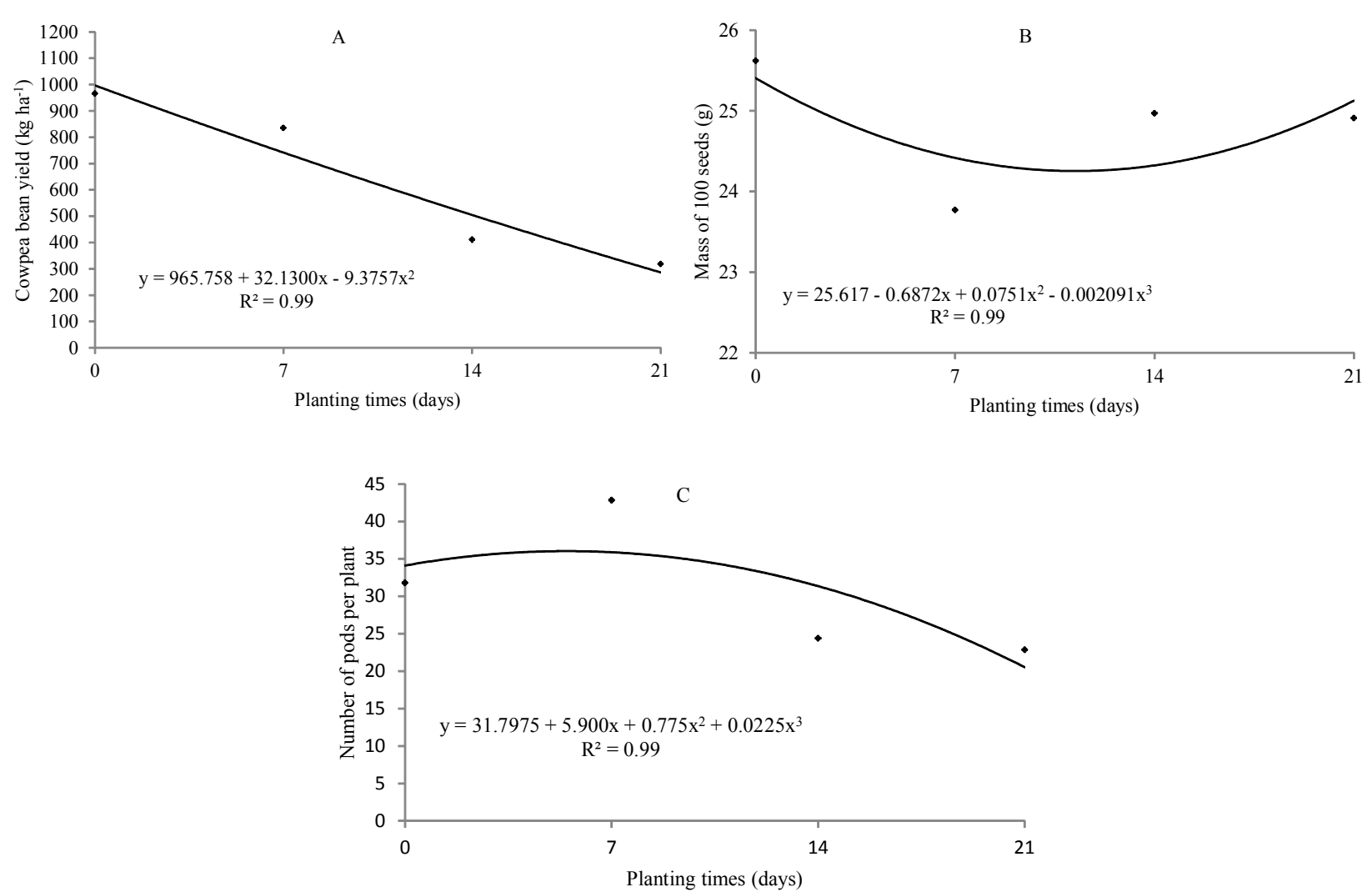

Figure 2 - Influence of the relative planting times of the cowpea bean on cowpea bean yield (A), mass of 100 seeds (B) and number of pods per plant (C). Macaíba, Rio Grande do Norte, 2012.

Ciênc. agrotec., Lavras, v. 37, n. 6, p. 531-537, nov./dez., 2013
No significantly differences were seen between the treatments for the number of fruit per plant, an important parameter in determining production. The general medium found for this variable in the intercropping was higher than those found by Ozkan, Curat and Kulat (2012) for five genotypes and inferior to the results found by Dogan and Zeybek (2009). Bhatti, Ahmad and Nazir (2005) observed a reduction of $26.74 \%$ in the number of fruit per plant when the sesame was intercropped with cowpea bean.

Related to the number of fruitful branches, the treatment 14 days outdidthe other ones. Its medium valour (7.75) was $31.60 \%$ larger than the average obtained for the other treatments (4.59) (Figure 2C). The values found for intercropping were higher than other authors with the monocrop of the Pedaliaceae (DOGAN; ZEYBEK, 2009). Ozkan Curat and Kulat (2012) obtained, using 12 genotypes, mediums that varied from 4.20 to 9.40. Jooyban and Moosavi (2012) related adecreasein vegetal competition in the sesame intercropping to the increase of the number of branches and the number of fruit per plant. 
According to Ozkan, Curat and Kulat (2012), the number of fruitful branches is responsive to the vegetable density, its values being, inversely proportional to the number of plants. It is probable that the increase in the interspecific competition may very well be important in this characteristic. Nevertheless, in this study a marked relationship was not verified between the increase of the interspecific competition and the decrease in number of fruitful branches. Anitha et al. (2010) verified a positive correlation between the number of fruitful branches and the number of fruitful per plant of the genotype TMV4 and between the number of fruitful branches and the yield per plant in the genotypes TMV4 and CS601. Such information is important to confirm the number of fruitful branches as an important component for the sesame yield. The apparent unconformity in data as far has the number of fruitful branches and the number of fruit per plant that did not accompany the values found for the yield may be explained by the possibility that the factor number of seeds per fruit (parameter not analyzed in this study) could very well have been a determinant factor in the behavior yield. Comparing four species of sesame planting in Egypt, Hendawey and Farag (2010) found yield values that disagree as far as the number of fruitful branches and fruit per plant but agree as far as the number of seeds per plant. Ijlal et al. (2011) consider the number of seeds per pod an important component of production, which may reflect the productive potential of each sesame fruit.

As far as the parameters for the cowpea bean, significant effectsof the treatments were noticed for cowpea bean yield, mass of 100 seeds and number of pods per plant. There were no meaningfull differences between the treatments for the number of seeds per pod.

Evaluating the effect of the planting times in the yield of the cowpea bean, it was noticed a progressive reduction for the values as the measure of time in its planting increased that of the sesame. The productivity of the Fabaceae was largest when it seeded at the same time and seven days after the Pedaliaceae, when compared to the other treatments. The competitive pressure exerted by the sesame was even more evident for the planting times of 14 and 21 days, when the reduction of yield decreased regarding the first plating time that was of $57.43 \%$ and $67.09 \%$, respectively (Figure 2A). The highest yield found by Udom, Fagam and Ekwere (2006) for the cowpea bean intercropped with sesame was of $1313 \mathrm{~kg} \mathrm{ha}^{-1}$. Santos, Grangeiro and Oliveira (2011) in the State of Paraíba, Brazil and Torres et al. (2008) in the State of Rio Grande do Norte, Brazil, for the cultivars BRS Potiguar, reached a productivity of 1073 and $1510 \mathrm{~kg} \mathrm{ha}^{-1}$, respectively in a conventional crop system. Studying the effect of relative planting times of corn in intercropping with cowpea bean Mauá cultivar, Guedes et al. (2010), observed that when both species were seeded at the same time there was a reduction of $22.64 \%$ in the yield of the green grain of the cowpea bean when compared to the single bean culture. Intercropping the cultivars Pretinho Precoce 1, UFRR Grão Verde, BRS Guariba and BRS Mazagão of cowpea bean with cassava in the State of Roraima, Alves et al. (2009) found medium values of productivity of the cowpea bean that varied from 1050.23 to $2436.67 \mathrm{~kg} \mathrm{ha}^{-1}$.

As far as the mass of 100 seeds it was not noted a lessening of its values as the planting of cowpea bean was delayed. The treatment 21 days ( 21 days) provided a medium value $2.77 \%$ less than the treatment 0 day (Figure 2B). The values found in this study for the mass of 100 seeds were superior to those obtained by Santos, Grangeiro and Oliveira (2011) and Torres et al. (2008) for the cultivars BRS Potiguar in monocropping and those reached by Udom, Fagam and Ekwere (2006) for the cowpea bean intercropped with sesame using a local variety.

The number of pods per plant was the most strongly affected characteristic by the delay in the seeding in relationship to the sesame. The effects of competitive pressure from sesame overthe cowpea bean along the seeding times of the Fabaceae were larger when the cowpea bean was planted 14 and 21 days after the Pedaliaceae. The highest value for this parameter was obtained for 7 days (42.85). The medium value found forthe treatments 14 days and 21 days was $44,88 \%$ smaller than the value found for the treatment 7 days (Figure 2C). The mediums found in this work for all treatments were superior to the ones found by Torres et al. (2008) and Udom, Fagam and Ekwere (2006).

Having to do with agroecossystem through LER, an advantage was noticed in intercropping compared to the monocropping. The medium values varied from 1.03 (21 days) to 1.30 ( 7 days) with the increase of 3 to $30 \%$ of the intercrop in relation to the single cultures, where the cowpea bean planting had more advantages, according to LER, 7 days after the seedling of the sesame (Figure 3). Even if the LER had indicated a more efficient use of natural resources and a potential increase in the total yield for all the treatments in the intercropping, according to Wang et al. (2012), this does not always compare closely to the input/output of the yield of the production. Nonetheless, it is not improbable that the increase in the LER values not only reflects a higher agricultural biodiversity of the farm, but may also be related to the cost reductions of expenses, including labor and consequently tied to the economic profit. 


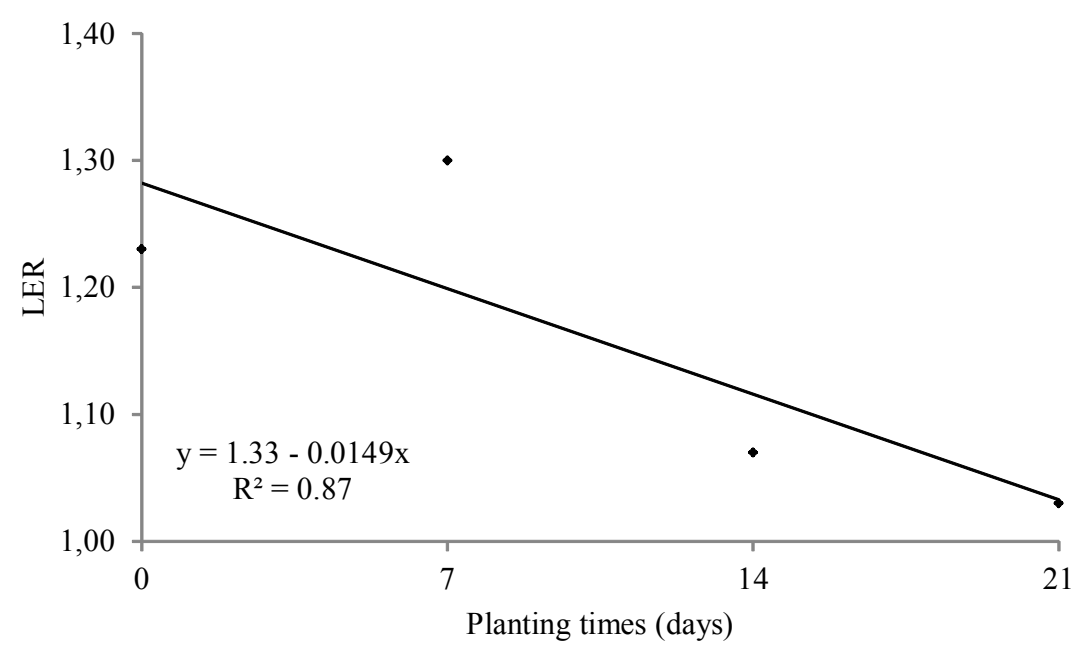

Figure 3 - Influence of the relative planting times of the cowpea bean on UET. Macaíba, Rio Grande do Norte, 2012.

\section{CONCLUSIONS}

There was an influence of the relative planting times over the sesame and cowpea bean yield components. The different relative planting times of the cowpea bean determined distinct competitive relationships between the intercropped cultures involved. According to LER data, the intercropping of sesame and cowpea bean, when the cowpea bean was seeded 7 days after the sesame, the area was better used, so there is a higher possibility of an increase in liquid gain for the famer.

\section{REFERENCES}

ALBUQUERQUE, F. A. de et al. Ecofisiologia do gergelim (Sesamum indicum L.). In: BELTRÃO, N. E. de M.; OLIVEIRA, M. I. P. de. (editores técnicos). Ecofisiologia das culturas de algodão, amendoim, gergelim, mamona, pinhão-manso e sisal. $2^{\mathrm{a}}$. ed. Brasília: Embrapa, 2012. p. 122-143.

ALVES, J. M. A. et al. Avaliação agroeconômica da produção de cultivares de feijão-caupi em consórcio com cultivares de mandioca em Roraima. Revista Brasileira de Agroambiente, Boa vista, v. 3, n. 1, p. 15-30, jan/jun, 2009.

ANDRADE JÚNIOR, A. S. de et al. Cultivo do feijão caupi, Brasília: CNPTIA, 2003.50 p. (Sistemas de produção, EMBRAPA - CNPTIA. n. 2.).

ANITHA, B. K. et al. Character association analysis in sesame (Sesamum indicum L.). Electronic Journal of Plant Breeding, v. 1, n. 2, p. 209-211, mar., 2010.
ARRIEL, N. E. C.; BELTRÃO, N. E. de M.; FIRMINO, P. de T. (Ed.). Gergelim: o produtor pergunta, a Embrapa responde. Brasília: Embrapa Informação Tecnológica, 2009. 209 p.

BEDOUSSAC, L.; JUSTES, E. A comparison of commonly used indices for evaluating species interactions and intercrop efficiency: Application to durum wheat-winter pea intercrops. Field Crops

Research, v. 124, p. 25-36, oct., 2011.

BELTRÃO, B. A. et al. Projeto cadastro de fontes de abastecimento por água subterrânea - diagnóstico do município de Macaíba, estado do Rio Grande do Norte. Recife: CPRM/PRODEEM, 2005.25 p.

BELTRÃO, N. E. de M. et al. Época relativa de plantio no consórcio mamona e gergelim. Revista verde de agroecologia e desenvolvimento sustentável grupo verde de agricultura alternativa, Mossoró, v.5, n.5 (Special Number), p. 67-73, out/dez., 2010.

BHATTI, I. H. et al. Agronomic performance of mash bean as an intercrop in sesame under different planting patterns. Emirates Journal of Food and Agriculture, Abu Dhabi, v. 25, n. 1, p. 52-57, jan., 2013.

BHATTI, I. H.; AHMAD, R.; M. NAZIR, M. S. Agronomic traits of sesame as affected by grain legumes intercropping and planting patterns. Pakistan Journal of Agricultural Sciences, Faisalabad, v. 42, n.1-2, p. 5660, jun., 2005. 
DOGAN, T.; ZEYBEK, A. Improving the traditional sesame seed planting with seed pelleting. African Journal of Biotechnology, Nairobi, v. 8, n. 22, p. 61206126, nov. 2009.

EGBE, O. M. Effects of plant density of intercropped soybean with tall sorghum on competitive ability of soybean and economic yield at Otobi, Benue State, Nigeria.Journal of Cereals and Oilseeds, v. 1, n. 1, p. 110, jun., 2010.

FAO. FAOSTAT. Disponível em: < http://faostat.fao.org/ site/339/default.aspx >. Acesso em 15 jan 2013.

GUEDES, R. E. et al. Consórcios de caupi e milho em cultivo orgânico para produção de grãos e espigas verdes. Horticultura Brasileira, Brasília, v. 28, n. 2, p. 174-177, abr./ jun., 2010.

HENDAWEY, M. H.; FARAG, H. I. A. Comparative studies between some sesame cultivars grown under different edaphic and climatic conditions. Arab Universities Journal of Agricultural Sciences, Cairo, v. 18, n. 1, p.97-121, jan., 2010.

IJLAL, Z. et al. Effects ofweed crop competition period on weeds And yield and yield components of sesame (Sesamum indicum L.). Pakistan Journal of Weed Science Research, v. 17, n. 1, p. 51-63, jan./mar., 2011.

JOOYBAN, Z.; MOOSAVI, S. G. Seed yield and some yield components of sesame as affected by irrigation interval and different levels of $\mathrm{N}$ fertilization and superabsorbent. African Journal of Biotechnology, Nairobi, v. 11, n. 49, p. 10944-10948, jun., 2012.

LANGHAM, D. R. Phenology of sesame. In: JANICK, J.; WHIPKEY, A. (Ed.). Issues in New crops and New Uses. Alexandria, USA: ASHS Press, 2007. p. 144-182.

LIMA, J. M. P. de et al. Feijão macassar: do plantio à colheita. Natal: Emparn, 2010.28 p. (Circuito de Tecnologias Adaptadas para a Agricultura Familiar, 7).
OGBONNA, P. E.; UMAR-SHAABA, Y. G. Yield responses of sesame (Sesamium indicum L.) to rates of poultry manure application and time of planting in a derived savannah ecology of south eastern Nigeria. African Journal of Biotechnology, Nairobi, v. 10, n. 66, p. 14881-14887, oct., 2011.

OZKAN, A.; CURAT, D.; KULAK, M. African Journal of Agricultural Research, Nairobi, v. 7, n. 19, p. 30293033, mai., 2012.

RANGKADILOK, N. et al. Variation of sesamin, sesamolin and tocopherols in sesame (Sesamum indicum L.) seeds and oil products in Thailand. Food Chemistry, v. 122,724-730, oct., 2010.

SANTOS, J. F. dos; GRANGEIRO, J. I. T.; OLIVEIRA, M. E. de C. Produção de cultivares de feijão-macáçar no Brejo paraibano. Tecnologia \& Ciência Agropecuária, João Pessoa, v.5, n.2, p.17-21, jun., 2011.

SUDDHIYAM, P. et al. Fertilizers for organic sesame.

Asian Journal of Food and Agro-Industry, Bangkok, v. 2, Special Issue, p.197-204, aug. 2009.

TORRES, S. B. et al. Produtividade e morfologia de acessos de caupi, em Mossoró, RN. Horticultura Brasileira, Brasília, v. 26, n. 4, p. 537-539, oct./dec., 2008.

UDOM, G. N.; FAGAM, A. S.; EKWERE, E. Effect of intra-row spacing and weeding frequency on the yield performance of sesame/cowpea intercrop.

EmiratesJournal of Food and Agricultural Sciences, Abu Dhabi, v. 18, n. 2, p. 52-60, jul., 2006.

VAN ASTEN, P. J. A. et al. Agronomic and economic benefits of coffee-banana intercropping in Uganda's small holder farming systems. Agricultural Systems, v. 104, p. 326-334, apr., 2011.

WANG, Q. et al. Research on Efficiency improving technology for intercropping sesame (Sesamum indicum) and peanut (Arachis hypogeae). Agricultural Science and Technology, Hunan, v. 13, n. 2, p. 324-329, feb., 2012. 